\title{
Behavioral responses of Nile tilapia (Oreochromis niloticus) by sublethal exposure to chlorpyrifos: a case study in Twin Lakes of West Sumatra
}

\author{
Taufiq Ihsan* ${ }^{\circledR}$, Tivany Edwin, Winna Anggraeni \\ Department of Environmental Engineering, Faculty of Engineering, Andalas University, Kampus Unand Limau Manis, Padang, West \\ Sumatra 25163, Indonesia
}

\begin{abstract}
Background: The most commonly used insecticide by $99.8 \%$ farmers in West Sumatra, is chlorpyrifos which contains organophosphates. Chlorpyrifos is used to kill insects and other pests and works as the contact poison, gastric toxins, and inhalation. It is very useful for farmers in keeping the plants such as corn, citrus, peanuts, and so forth. Chlorpyrifos can enter the water body with direct application to control pests or indirectly through either spraying or washing during high rainfall in spray applications for plant leaves. Chlorpyrifos is also used in farming in the region of Twin Lakes (Diatas Lake and Dibawah Lake), West Sumatra, Indonesia. One of the most important fish that is cultivated in this region is Nile tilapia (Oreochromis niloticus).

Methods: The acute toxicity $\left(\mathrm{LC}_{50}-96 \mathrm{~h}\right)$ of chlorpyrifos for Nile tilapia in studies was $0.076 \mathrm{mg} / \mathrm{L}$. Sublethal concentrations used for the studies were one-seventh $(0.011 \mathrm{mg} / \mathrm{L})$ and one-fourteenth $(0.005 \mathrm{mg} / \mathrm{L})$ of the $\mathrm{LC}_{50}-96 \mathrm{~h}$. The test animal was exposed to the both sublethal concentrations for 1,7 and 14 days. Behavioral responses were studied in the experimental periods. Tilapia that exposed chlorpyrifos exposure was exhibited irregular body movements, gills and fins motion, mucus secretion, breathing at the surface, and anal excretion.

Results: It was revealed that the longer the exposure time, the more visible behavioral changes in fish, as well as the concentration variations, it means that the higher the concentration, the more visible changes in physiological behavior of fish. Correlation values (R) were was 0.75-0.99.

Conclusion: These behavioral responses can be used as a tool in biomonitoring program to monitor ecotoxicity risk of chlorpyrifos to the test species, especially in the region of Twin Lakes, West Sumatra, Indonesia.

Keywords: Chlorpyrifos, Lakes, Animals, Farmers, Environmental monitoring

Citation: Ihsan T, Edwin T, Anggraeni W. Behavioral responses of Nile tilapia (Oreochromis niloticus) by sublethal exposure to chlorpyrifos: a case study in Twin Lakes of West Sumatra. Environmental Health Engineering and Management Journal 2018; 5(4): 205-210. doi: 10.15171/EHEM.2018.28.
\end{abstract}

\section{Article History:}

Received: 23 July 2018

Accepted: 18 September 2018

ePublished: 10 October 2018

\section{Introduction}

The growth of agricultural sector in West Sumatra, Indonesia, reached $4.14 \%$, higher than the previous year which was $2.05 \%$ (1). Increased agricultural sector indirectly also increases the use of insecticides in agriculture. The most commonly used insecticide by $99.8 \%$ farmers in West Sumatera, Indonesia, is chlorpyrifos which contains organophosphates (2). Chlorpyrifos is also one of the 100 types of organophosphorus pesticides that have been circulating in the market. According to the World Health Organization (WHO) (3), chlorpyrifos in class II is hazardous. Chlorpyrifos is very toxic for vertebrates such as fish, birds, and mammals. It is used to kill pests and works as the contact poison, gastric toxins, and inhalation.
It is very useful for farmers in keeping the plants such as corn, citrus, peanuts, and so forth. Chlorpyrifos is also used to control more than 250 non-agricultural insects and anthropogenic pests such as underground termites, cockroaches, ticks, ants, and so on $(4,5)$. Chlorpyrifos was first registered in the United States in 1985 and up to now, it has been used by more than 98 countries, including developing countries. Lorsban and Dursban are commonly used names as chlorpyrifos (6). Chlorpyrifos is one of several organophosphate compounds applied by spraying. The entry of insecticides into water bodies can occur as a result of being carried by rainwater or surface streams originating from the spraying process. Insecticides dissolved in water will be absorbed by mud, plankton, 
algae, aquatic avertebrates, aquatic plants, fish, and so on (3). Chlorpyrifos enters the environment through direct application to plants, grasses or through evaporation, spillage, and chlorpyrifos waste disposal. Swallowing chlorpyrifos orally through contaminated food in a container, in the case of children putting objects from the hands in their mouth after touching chlorpyrifos, may cause some symptoms (7). Laboratory and field studies have shown that chlorpyrifos readily decomposes rapidly in water. Laboratory studies showed that chlorpyrifos is added to pure water with a neutral $\mathrm{pH}$, and then to soil. The half-life of chlorpyrifos is about a month with water and light (photolysis), which contributes to detoxification and damage. The more alkaline soil conditions result in faster damage with half-life of about 2 weeks (6) . Chlorpyrifos is also used in farming in the region of Twin Lakes of West Sumatra, Indonesia. One of fish cultured in this region is Nile tilapia (Oreochromis niloticus). If the contamination of agricultural insecticides enters the waters where fish are cultured, it will affect fish survival and growth rate. In addition to fish consumed by the local community, Nile tilapia is often used as a toxicity test animal because it can respond to the physical changes of water and to the presence of pollutant compounds dissolved within certain tolerance limits (8-10). The sublethal test is one of the most common methods used to determine the early symptoms of fish poisoning $(11,12)$. The effect of sublethal toxicity on fish is a change in learning ability or a response to natural stimuli, such as responses to salinity and temperature, lack of swimming ability and physical stress, reduced growth rate and physiological and biochemical changes, histopathological abnormalities in the gills, liver, kidneys and blood vessels, and accumulation in tissues and eggs $(11,12)$. Special attention should be paid to the contamination of water by insecticides since fish exposed to water contaminated by insecticides at sublethal concentrations will absorb the active ingredient through body surface, gill membrane, and cuticle diffusion. The absorption will take place continuously until the steady state is reached, that is, the condition in which the amount of test material is absorbed and the unity of the union is balanced at a concentration of the material in water. The number of test animals used in the subcategory of behavioral observation is very influential, as the fewer fish in an aquarium test (at least 5 test species per aquarium), the easier it is to observe the behavioral changes in fish (13). Sublethal toxicity test is one of the most commonly used methods to determine the initial symptoms of fish poisoning by xenobiotic. This research was carried out in a laboratory scale before being continued with natural samples. These behavioral responses studies can be used as a tool in biomonitoring program to monitor ecotoxicity risk of chlorpyrifos to the test species, especially in the region of Twin Lakes, West Sumatra, Indonesia.

\section{Material and Methods}

This study was conducted in Twin Lakes of West Sumatra. Twin Lakes is located in Danau Kembar district, Solok Regency in the West Sumatra province. The distance between Twin Lakes and Padang, the capital city of West Sumatra, is about $60 \mathrm{~km}$, and it takes about one hour and a half from Padang. As the name implies, the Twin Lakes consists of two adjacent lakes. The distance between the lakes is about $300 \mathrm{~m}$. These lakes actually have different names. The first lake is called Diatas Lake, and the second one is called Dibawah Lake (14). The location of Twin Lakes in the West Sumatra province is shown in Figure 1. In this area, especially in Dibawah Lake, there is agricultural land which is a source of income for the residents such as cabbage, chili, potato and various other vegetables and fruits. And in the Diatas Lake, fish cultivation is the sources of income for the residents. Chlorpyrifos concentration was measured in this area. According to the results, chlorpyrifos concentration is $0.007 \mathrm{mg} / \mathrm{L}$ in this area (15). The test animals used in this study were 120 healthy and active Nile tilapia with a weight of 2-3 g, average size of $4-5 \mathrm{~cm}$, and age of about 1 month because at this age, the test animals are more sensitive to the toxic material than the more mature fish (16). Also, 9 acrylic aquariums $(35 \times 30 \times 30 \mathrm{~cm})$ were used in this study. The

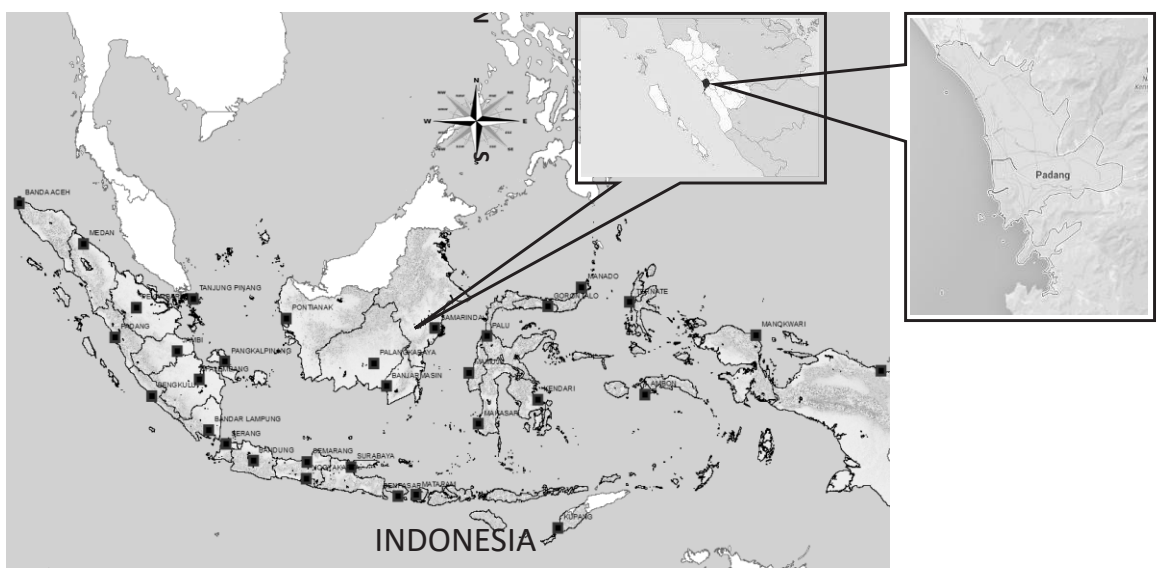

Figure 1. Location of the study area. 
size of the aquariums was based on the weight of the test animals used in this study, referring to USEPA standard (16).

\section{Acclimatization of test animal}

Test animals were acclimatized to the water used as a control. The water was conditioned having dissolved oxygen (DO) above $3 \mathrm{mg} / \mathrm{L}$, temperature between $25-30^{\circ} \mathrm{C}$ and $\mathrm{pH}$ between 6-9 (16). Maintenance water replacement would done when the condition was too cloudy. The test animals' food was given daily in the form of fish pellets.

\section{Acute toxicity test}

Acute toxicity test was performed with 96-hour observation time on an artificial chlorpyrifos. For this purpose, chlorpyrifos under the trade name Dursban, which is used by farmers in the region of Twin Lakes, West Sumatra, was used in this study. The test results may be accepted if $90 \%$ of the test animals at the end of the observation control, are alive. If the survival rate is smaller than $90 \%$ then, the test should be repeated. Acute toxicity tests consist of the preliminary and baseline tests. The preliminary test was performed to determine the concentration range of chlorpyrifos to be tested in the baseline test. In the preliminary test, the variation of concentration of chlorpyrifos was $0,0.01,0.1,1,10$, and $100 \mathrm{ppm}$ (16). Each aquarium on a preliminary test had a capacity of $10 \mathrm{~L}$ and contained 10 fish (17). The baseline test was performed to determine the true $\mathrm{LC}_{50}-96 \mathrm{~h}$ value of chlorpyrifos. The sublethal toxicity test was performed for 14 days to evaluate the effect of chlorpyrifos on the physiological and behavioral responses of Nile tilapia (18). Physiological and behavioral responses of 45 fish can be observed through body movements, gill lid movements, fins motion, mucus, breathing at the surface and anal excretion. The concentration used in this test was oneseventh of $\mathrm{LC}_{50}-96 \mathrm{~h}$ and one-fourteenth of $\mathrm{LC}_{50}-96 \mathrm{~h}$ $(18,19)$. The experiment was repeated three times. The behavioral changes of Nile tilapia were observed during the exposure time. Data were analyzed using regression and correlation methods and scoring system (only for anal excretion).

\section{Results}

During the acclimatization period, $\mathrm{pH}$ was $8.1-8.6$, DO 4.1-9 mg/L, and temperature $28.6-29.7^{\circ} \mathrm{C}$. This culture medium for acute toxicity test was appropriate and acceptable $(10,16)$.

\section{Preliminary test}

The percentage of average mortality rate of tilapia obtained in the preliminary test for 96 hours is shown in Figure 2. As shown in Figure 2, the higher the pollutant concentration, the larger the number of deaths in the test animals and vice versa, the smaller the pollutant concentration, the smaller the number of deaths in the test animals. At concentrations

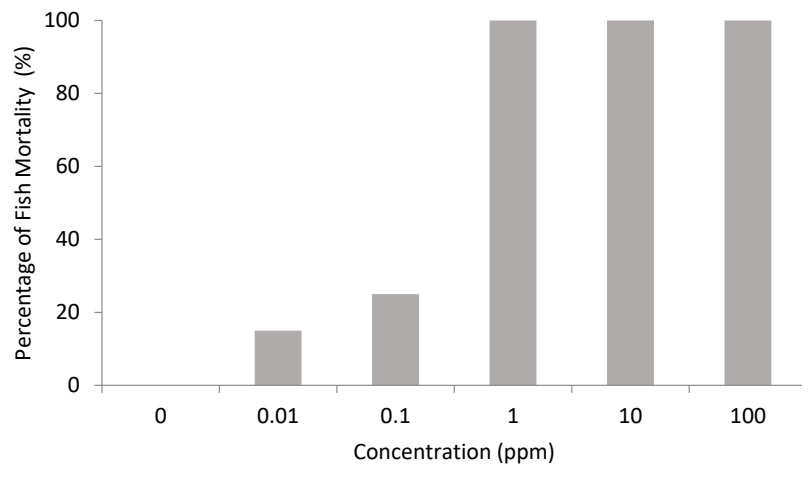

Figure 2. Percentages of tilapia mortality in the preliminary test.

of 1,10 , and $100 \mathrm{ppm}$, the mortality rate was $100 \%$ and at a concentration of $0.01 \mathrm{ppm}$, the mortality rate was $15 \%$. This result indicates that toxic compounds in the test solution affect the death of test animals. $\mathrm{LC}_{50}-96 \mathrm{~h}$ values were determined based on the animal mortality rate at each concentration level. The methods used to estimate the $\mathrm{LC}_{50}-96 \mathrm{~h}$ values were graphical methods, SpearmanKarber method, trimmed Spearman-Karber method and Probit methods (20). The the method used in this study was selected based on the mortality rates of test animals. If at the acute toxicity test occurs two or more animal deaths on variation of toxicity concentration, the method used is Probit method. So the method used to estimate the value of $\mathrm{LC}_{50}-96 \mathrm{~h}$ in this study was Probit method due to the death of two or more animal tests at each concentration of waste (21). The data obtained were analyzed using Probit method and the interim $\mathrm{LC}_{50}-96 \mathrm{~h}$ of $0.089 \mathrm{ppm}$ with the upper limit of $0.256 \mathrm{ppm}$ and the lower limit of $0.028 \mathrm{ppm}$ was obtained.. Water quality parameters were measured in each aquarium during the preliminary test, at $\mathrm{pH} 7-8$, temperature $27-28.5^{\circ} \mathrm{C}$, and DO $>3 \mathrm{mg} / \mathrm{L}$. During the preliminary test, water quality was still within the recommended level for Nile tilapia maintenance. Therefore, it can be concluded that the mortality of fish was caused by chlorpyrifos dissolved in water testing.

Basic test

The percentage of average mortality rate of tilapia obtained from the basic test for 96 hours is presented in Figure 3. Figure 2 shows that the animal mortality rate was $100 \%$ at concentration $0.264 \mathrm{ppm}$ and $10 \%$ in the control aquarium. Based on the percentage of mortality rate of tilapia obtained from the baseline test, the fish were died at two or more concentrations, so the $\mathrm{LC}_{50}-96 \mathrm{~h}$ value can be determined using the probit method. The $\mathrm{LC}_{50}-96$ $h$ value was calculated by entering the number of deaths at each concentration into the probit program and the $\mathrm{LC}_{50}-96 \mathrm{~h}$ value obtained to be $0.076 \mathrm{ppm}$. The $\mathrm{LC}_{50}-96 \mathrm{~h}$ value for this type of insecticide belongs to a high toxicity type (very toxic). This value indicates that if chlorpyrifos enters into waters with concentration of $0.076 \mathrm{ppm}$, it can lead to $50 \%$ mortality in fish for 96 hours. Table 1 


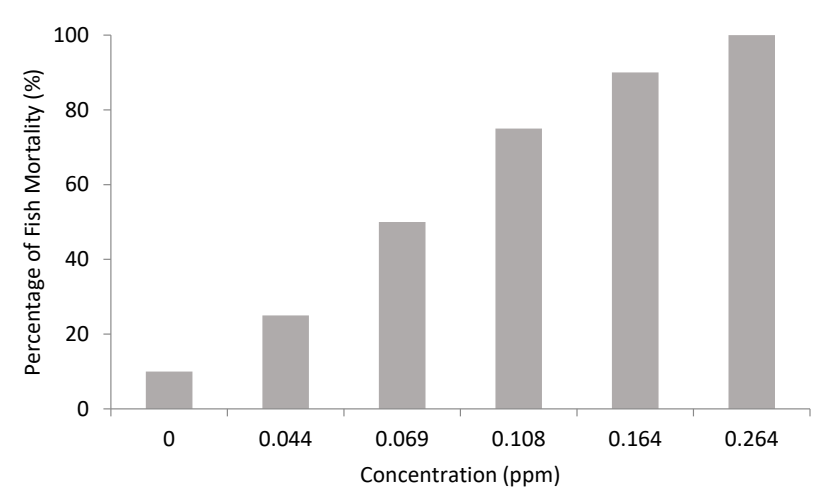

Figure 3. Percentages of tilapia mortality in the baseline test.

Table 1. Correlation coefficients of the behavioral changes of Nile tilapia to chlorpyrifos

\begin{tabular}{ll}
\hline Responses & R-value \\
\hline Body motion & 0.99 \\
Gills motion & 0.96 \\
Fins motion & 0.99 \\
Mucus production & 0.96 \\
Breathing at the surface & 0.75 \\
Anal excretion & 0.75 \\
\hline
\end{tabular}

shows the relationship between behavioral responses of Nile tilapia and exposure time and variations of sublethal concentration of chlorpyrifos. The longer the exposure time, the more visible behavioral changes, as well as the concentration variations, the higher the concentration, the more visible changes in physiological behavior of fish.

\section{Discussion}

The results showed that chlorpyrifos were highly toxic to fish life, but their toxicity would be less in fish larvae compared with more mature fish. This is evidenced by the standard range of $\mathrm{LC}_{50}$ values $(0.07-0.68 \mathrm{mg} / \mathrm{L})$ for adult fish (22). There was a decrease in fish body motion in normal condition every day at concentration of $0.005 \mathrm{ppm}$ and $0.011 \mathrm{ppm}$. Based on the coefficient of determination, got 0.99 as the correlation coefficient, which ranged between $0.800-1.000$ that means there was a very strong relationship between observation time and changes in body motion of tilapia. The change in body motion of tilapia has a significant effect on observation time so that the result of analysis can be accepted with concentration of $0.005 \mathrm{ppm}$. Infected fish have reduced gestures because chlorpyrifos already affects the nervous system and disrupts muscle movements so that fish begin to weaken and move irregularly. Similarly, Halappa and David reported that abnormal fish movements are caused by a lack of coordination of the nervous system and muscles due to the accumulation of acetylcholine in synaptic and neuromuscular junctions (18). Based on the coefficient of determination, got 0.96 as correlation coefficient which ranged between $0.800-1.000$, that means there was a very strong relationship between the observation time and gill motion. It is concluded that there was a significant relationship between gill motion and observation time at both concentrations. This indicates that the duration of exposure to chlorpyrifos in the water affected the gill motion of tilapia. The decrease of tilapia's operculum motion that is a fish response to reduce the absorption of toxins through the gills. This leads to a reduction in the average oxygen consumption of fish $(18,19)$. A regression model with a correlation coefficient of 0.99 ranging from $0.800-1.000$, means that there was a very strong relationship between the observation time and fins motion. This indicates that the duration of exposure to chlorpyrifos in water had an effect on the fins motion of tilapia. There was a significant influence on the fins motion of tilapia against the observation time for each concentration. Chlorpyrifos acts as a contact poison, when contacting directly with the fish body such as on the fins, then, the response of fish to changes in the fins motion can be visually seen, the motion of the left and right chest fins were not the same (23). Normally fish have little mucus on the body, if the fish are exposed to toxic substances in large quantities, then, the production of mucus will be visible to the naked eye. Regression model was calculated to be 0.96 . It means that there was a very strong relationship between the observation time and mucus. The excessive secretion of mucus is a specific response to toxins to reduce the direct contact of toxins with the skin (24). A regression model with a correlation coefficient of 0.75 ranging from 0.600 0.799 , where the level of relation strong between tilapia's breath at the surface and exposure of chlorpyrifos. It means that is the significant effect on the fish that breathe at the surface against the observation time at a concentration of $0.011 \mathrm{ppm}$, as well as the concentration of $0.005 \mathrm{ppm}$. Normally the fish occasionally breathe at the surface in the not-too-long time, but the fish exposed to chlorphyrifos exhibit another response is reduced appetite, , and no fear responses when human approached. High concentrations of chlorpyrifos toxins affect the percentage of fish that breathe at the surface. When fish comes to the surface of the water, it means that it is exposed to toxins and this behavior is the response of fish to easily get enough oxygen from the outside and reduce the stress of breathing that may be resulted from the increased need of fish for oxygen in the water or any respiratory organs that are going to be disturbed $(18,25)$. Anal excretion is associated with a large amount of metabolic waste released by fish through feces and urine into the water that is toxic to fish. As the number of anal excretion of fish cannot be determined, therefore, a scoring system ( $1=$ no excretion, $2=$ little excretion, $3=$ much excretion) can be used for every aquarium. Regression value of 0.75 got correlation coefficient ranged from $0.600-0.799$ with level of strong relationship between tilapia's excretion and exposure of chlorpyrifos. The condition of tilapia exposed weakens the immune system, so the body can be easily infected with bacteria. This is in accordance with a study by Pasnik et al 
(26) on tilapia feces infected with Streptococcus agalactiae. Infected fish showed symptoms such as loss of appetite, lethargy, erratic swimming, frosty and slimy white feces, sometimes left in the anus.

\section{Conclusion}

In the present study, the effect of sublethal toxicity of chlorpyrifos on the behavior of Nile tilapia (O. niloticus) was investigated and correlation coefficient of 0.75 ranging from 0.600-0.799 was obtained, indicating that the relationship between behavioral responses of tilapia and chlorpyrifos sublethal exposure was very strong. Therefore, it can be concluded that exposure time and variation of concentration have an effect on behavioral changes of Nile tilapia such as gestures, operculum, anal excretion and breathing at the surface of water, so that the longer the exposure time, the more visible behavioral changes in the fish, as well as the variation of concentration, it means that the higher the concentration, the more visible changes in the physiological behavior of the fish.

\section{Acknowledgements}

The authors would like to gratitude Department of Environmental Engineering, Faculty of Engineering, Andalas University, which assisted in the research and also all others involved in the realization of this study.

\section{Ethical issues}

The authors hereby certify that all data collected during the study are as stated in the manuscript, and no data from the study has been or will be published separately elsewhere.

\section{Competing interests}

The authors declare that they have no conflicts of interests.

\section{Authors' contributions}

The authors contributed and were involved in the suggestion of the problem, design of experiments, data collection, and article approval.

\section{References}

1. West Sumatera Province Central Bureau of Statistics. Perkembangan sektor pertanian provinsi Sumatera barat 2015. BPS sumbar. [cited 2018 July 13] Available from: https://sumbar.bps.go.id/publication/2016/09/30/63cd6ba 18ae702d6d1ccecfd/ringkasan-eksekutif-perkembangansektor-pertanian-provinsi-sumatera-barat-tahun-2015. [In Indonesian].

2. Kegiatan Penelitian. Komposisi kegiatan badan litbang pertanian. [cited 2018 Jul 13] Available from: http://www. litbang.pertanian.go.id/spp/pdf-file/statistik2016/5Kegiata nStatistik2016.pdf. [In Indonesian].

3. World Health Organization (WHO). The Who Recommended Classification of Pesticides by Hazard and Guidelines to Classification 2009. Geneva: WHO; 2010.
4. Matsumoto ST, Mantovani MS, Malaguttii MI, Dias AL, Fonseca IC, Marin-Morales MA. Genotoxicity and mutagenicity of water contaminated with tannery effluents, as evaluated by the micronucleus test and comet assay using the fish Oreochromis niloticus and chromosome aberrations in onion root-tips. Genet Mol Biol 2006; 29(1): 148-58. doi: 10.1590/S1415-47572006000100028.

5. Sun F, Chen HS. Monitoring of pesticide chlorpyrifos residue in farmed fish: investigation of possible sources. Chemosphere 2008; 71(10): 1866-9. doi: 10.1016/j. chemosphere.2008.01.034.

6. Chlorpyrifos Protects. Chlorpyrifos FAQs. 2016 [cited 2018 July 17]. Available from: https://www.chlorpyrifos.com/ faqs.html.

7. Agency for Toxic Substances and Disease Registry (ATSDR). Toxicological profile for chlorpyrifos. [cited 2018 July 17]. Available from: https://www.atsdr.cdc.gov/ toxprofiles/tp84.pdf.

8. Popma T, Masser M. Tilapia Life History and Biology. Stoneville, Mississippi: Southern Regional Aquaculture Center (SRAC); 1999.

9. Wright DA, Welbourn P. Environmental Toxicology. Cambridge: Cambridge University Press; 2002. doi: 10.1017/CBO9780511805998.

10. Rice EW, Baird RB, Eaton AD, Clesceri LS, editors. Standard Methods for the Examination of Water and Wastewater. USA: American Public Health Association (APHA), American Water Works Association(AWWA), Water Environment Federation (WEF); 2012.

11. Lu FC, Kacew S. Lu's Basic Toxicology, Fundamentals, Target Organs, and Risk Assessment. 4th ed. London, New York: Taylor and Francis; 2002.

12. Soemirat J. Toksikologi Lingkungan. 3rd ed. Yogyakarta: Gajah Mada Press; 2009. [In Indonesian].

13. Suryani A, Aunurohim A. Paparan sub lethal insektisida diazinon 600 EC terhadap pertumbuhan ikan Mujair (Oreochromis mossambicus). Jurnal Sains dan Seni ITS 2013; 2(2): E191-6. doi: 10.12962/j23373520.v2i2.4066. [In Indonesian].

14. Solok Regency Central Bureau of Statistics. Kabupaten Solok Dalam Angka 2015. [cited 2018 Jun 19] Available from: https://solokkab.bps.go.id/publication/2016/05/03/ f35eee $1 \mathrm{ab} 569 \mathrm{f} 4 \mathrm{e} 34 \mathrm{c} 6 \mathrm{~d} 4 \mathrm{~b} 8 \mathrm{f} / \mathrm{kab}$ upaten-solok-dalamangka-2015.html.

15. Ihsan T, Edwin T, Husni N, Rukmana WD. Uji toksisitas akut dalam penentuan LC50-96H insektisida klorpirifos terhadap dua jenis ikan budidaya danau Kembar, Sumatera Barat. Jurnal Ilmu Lingkungan 2018; 16(1): 98- 103. doi: 10.14710/jil.16.1.98-103. [In Indonesian].

16. United States Environmental Protection Agency (EPA). Methods for Measuring the Acute Toxicity of Effluents and Receiving Waters to Freshwater and Marine Organisms. 5th ed. Washington, DC: EPA; 2002.

17. OECD iLibrary. OECD Guidelines for the Testing of Chemicals, Section 2. [cited 2018 July 11] Available from: https://www.oecd-ilibrary.org/environment/oecdguidelines-for-the-testing-of-chemicals-section-2-effectson-biotic-systems_20745761.

18. Halappa R, David M. Behavioural responses of the freshwater fish, Cyprinus carpio (Linnaeus) following sublethal exposure to chlorpyrifos. Turkish Journal of 
Fisheries and Aquatic Sciences 2009; 9: 233-8. doi: 10.4194/ trjfas.2009.0218.

19. Singh RN, Pandey RK, Singh NN, Das VK. Acute toxicity and behavioral responses of common carp Cyprinus carpio (Linn.) to an organophosphate (dimethoate). World Journal of Zoology 2009; 4(2):70-5.

20. Rand GM. Fundamentals of Aquatic Toxicology: Effects, Environmental Fate and Risk Assessment. 2nd ed. Washington, DC: Taylor \& Francis; 1995. p. 1125.

21. Ihsan T, Edwin T, Vitri RY. Analisis LC50 logam Pb, Co dan Cr terhadap ikan mas (Cyprinus carpio. L) pada limbah cair industri percetakan kota Padang. Dampak Jurnal Teknik Lingkungan 2017; 14(2): 98-103. doi: 10.25077/ dampak/14/2/98-103/2017. [In Indonesian].

22. Johnson WW, Finley MT. Handbook of Acute Toxicity of Chemicals to Fish and Aquatic Invertebrates: Summaries of Toxicity Tests Conducted at Columbia National Fisheries Research Laboratory, 1965-78. Washington, DC: US Fish and Wildlife Service; 1980.

23. Padmanabha A, Reddy HR, Khavi M, Prabhudeva KN,
Rajanna KB, Chethan N. Acute effects of chlorpyrifos on oxygen consumption and food consumption of freshwater fish, oreochromis mossambicus (peters). International Journal of Recent Scientific Research 2015; 6(4): 3380-4.

24. Botte ES, Jerry DR, Codi King S, Smith-Keune C, Negri AP. Effects of chlorpyrifos on cholinesterase activity and stress markers in the tropical reef fish Acanthochromis polyacanthus. Mar Pollut Bull 2012; 65(4-9): 384-93. doi: 10.1016/j.marpolbul.2011.08.020.

25. Toledo-Ibarra GA, Diaz-Resendiz KJ, Pavon-Romero L, Rojas-Garcia AE, Medina-Diaz IM, Giron-Perez MI. Effects of diazinon on the lymphocytic cholinergic system of Nile tilapia fish (Oreochromis niloticus). Vet Immunol Immunopathol 2016; 176: 58-63. doi: 10.1016/j. vetimm.2016.05.010.

26. Pasnik DJ, Evans JJ, Klesius PH. Fecal strings associated with Streptococcus agalactiae infection in Nile tilapia, Oreochromis niloticus. The Open Veterinary Science Journal 2009; 3: 6-8. doi: 10.2174/1874318809003010006. 